\title{
関節リウマチに用いる生物学的製剤による重篤な感染症の解析 一日米の有害事象自発報告データベースを用いてー
}

\author{
豕瀬＼cjkstart諒，細見光一*，朴ピナウル，藤本麻依，高田充隆 \\ 近畿大学薬学部 臨床薬学部門 臨床薬剂情報学分野

\section{Signal Detection of Serious Infections Following Treatment with Biologics for Rheumatoid Arthritis: Data Mining of the FDA Adverse Event Reporting System and Japanese Adverse Drug Event Report Databases}

Ryo Inose, Kouichi Hosomi ${ }^{*}$, Binawool Park, Mai Fujimoto and Mitsutaka Takada Division of Clinical Drug Informatics, School of Pharmacy, Kinki University

\author{
[Received March 26, 2014 ] \\ (Accepted August 6, 2014 )
}

\begin{abstract}
To examine the association between biologics for rheumatoid arthritis and serious infections (hepatitis B, hepatitis C, tuberculosis, pneumonia and sepsis), we analyzed the US Food and Drug Administration Adverse Event Reporting System (FAERS) and the Japanese Adverse Drug Event Report database (JADER) of Pharmaceuticals and Medical Devices Agency (PMDA). The reporting odds ratio was calculated and used to detect spontaneous report signals, with detection defined as a lower limit $>1$ in a $95 \%$ confidence interval. In addition, time to onset and age at onset of tuberculosis were investigated. Drug-reaction pairs were identified in both FAERS $(\mathrm{n}=29,017,485)$ and JADER $(\mathrm{n}=$ $2,079,653)$. In both databases, significant associations were observed between biologics and infections (hepatitis B, tuberculosis, pneumonia and sepsis). JADER data revealed a significant association of etanercept with hepatitis C. In FAERS, the majority of tuberculosis events, associated with all drugs, were observed within 1 month of administration, whereas most tuberculosis infections associated with biologics were observed during the 5 months following administration. In JADER, most cases of tuberculosis associated with all drugs and with biologics, respectively, were observed during the 2 months after administration. In conclusion, hepatitis $\mathrm{C}$ associated with etanercept treatment should be closely monitored in clinical practice. In addition, tuberculosis associated with biologics should be carefully monitored for 5 months following drug administration. Further studies are needed to confirm these findings.
\end{abstract}

Key words — rheumatoid arthritis, biologics, serious infections, FAERS, JADER

\section{緒言}

近年，関節リウマチの治療に生物学的製剂が使 用され，対症療法が中心であった治療目標は疾患 の寛解へと変化した。 日本リウマチ学会の生物学 的製浏関連の各ガイドラインく関節リウマチに対 するアバタセプト使用ガイドライン（http://www. ryumachi-jp.com/info/guideline_ABT_100930.html, 2012 年 4 月 25 日), 関節リウマチに対する TNF 阻害薬使用ガイドライン（http://www.ryumachi-jp.
com/info/guideline_TNF_120704.html, 2012 年 8 月 7 日), 関節リウマチに対するトシリズマブ使用 ガイドライン（http://www.ryumachi-jp.com/info/ guideline_TCZ_120704.html, 2012 年 8 月 7 日) >等 では，その有效性は高く評価されているが，同時 に多くの問題点が指摘されている.これらの生物 学的製剂は, $\mathrm{B}$ 型肝炎ウイルスの再活性化および 肝炎増悪が指摘されており，C型肝炎ウイルスに ついては一定の見解は得られていないが臨床上注 意が必要であるとされている，また，承認時より

\footnotetext{
* $\overline{7} 577-8502$ 大阪府東大阪市小若江3-4-1
} 
結核，肺炎，敗血症など感染症関連の重篤な有害 事象の発現が知られており注意喚起がなされてい る。特に結核は，ほかの事象に比べ発症の発見が 遅れることは，その間に患者が重症化し排菌量が 増加する可能性が高まることに加え，周囲への感 染リスクが増大する。 そのため, 結核発症の危険 性に焦点をあてた注意深いサーベイランスが必要 とされている. ${ }^{1)}$ 関節リウマチの治療に用いる生 物学的製剤の有害事象について薬剂別に検討した 報告は豊富にあるが, ${ }^{2-13}$ 同一データベースを用い て各生物学的製剂の有害事象を比較して検討した 報告や発現時期, 発現年齢について詳細に検討し た報告は我々の調査では確認されていない，有害 事象の発現傾向，発現時期，発現年齢を把握する ことにより臨床現場で生じる有害事象に対して, 個別かつ迅速な対応が可能になると考える.

有害事象自発報告データベースは医療安全性監 視システムのツールの1つとして注目されてい る。米国では Food and Drug Administration Adverse Event Report System (FAERS: http://www.fda.gov/ Drugs/GuidanceComplianceRegulatoryInformation/ Surveillance/AdverseDrugEffects/default.htm, 2014 年 3 月 19 日）, 日本では独立行政法人医薬品医療機 器総合機構（PMDA）が Japanese Adverse Drug Event Report database (JADER: http://www.info. pmda.go.jp/fukusayoudb/CsvDownload.jsp, 2014 年 3 月19日）として自発報告のデータを公開している.

データの構成として, FAERS は, 患者背景と 管理情報の DEMO テーブル，投薬情報の DRUG テーブル, 有害事象の REAC テーブル, 重症度 の OUTC テーブル, 報告情報源の RPSR テーブル， 投与開始日と終了日の THER テーブル, 処方目 的の INDI テーブルで構成されており，JADER は 症例一覧テーブル，医薬品情報テーブル，副作用 テーブル，原疾患テーブルで構成されている.

FAERS と JADER の有害事象の項目は Medical Dictionary for Regulatory Activities（MedDRA）の 基本語（preferred term: PT）に基づいている.

FAERS と JADER はいずれも Web からダウン ロード可能なデータセットが公開されており, FAERS は 2004 年〜 2009 年の 6 年間分で約 160 万 件の報告があり, JADER は 2004 年度以降の約 24
万件の報告がある䐍大なデータベースである．膨 大な量の情報を有する有害事象データベースから 薬剂による有害事象の発現傾向を把握するため に, 安全性シグナルを算出し数值化する手法が知 られている. ${ }^{14)}$ 代表的な手法として, 早期かつ多 数のシグナルの検出に適している reporting odds ratio（ROR）がある. ${ }^{15)}$ FAERS は米国に限らず, 日本を含め世界各国から報告がなされ, JADER は日本国内からの報告に限られている。両者を比 較することによって, 薬剤と有害事象の関連およ び海外と日本における発現傾向を把握することが 可能となり，臨床現場での活用が期待できる.

今回, 臨床で有害事象に対する個別かつ迅速な対 応に活用されることを目的とし, FAERS と JADER を用いて, 生物学的製剤による B 型肝炎, $\mathrm{C}$ 型肝炎, 結核, 肺炎, 敗血症の発現傾向を解析した. 結核に 関しては，発現時期，発現年齢も解析した.

\section{方法}

対象とした薬剤は関節リウマチに対して使用さ れる生物学的製剤である abatacept, adalimumab, etanercept, infliximab, tocilizumabの 5 種類とした. 対象有害事象は B 型肝炎, C 型肝炎, 結核, 肺炎, 敗血症とし, 項目はMedDRA の PT に基づいた (表1). 解析ッールとして Visual Mining Studio Ver 7.3 (NTT デー夕数理システム, 東京) を用い た. FAERS（2004 年第 1 期〜2009 年第 4 期）と JADER（2004 年 4 月〜2012 年 11 月）より, 同一 症例に対して複数の報告がデータベースに登録さ れている重複報告について症例情報を基に除外 し, 対象とする薬剤㧍よび有害事象を抽出し解析

表 1 対象有害事象

\begin{tabular}{ll}
\hline \hline $\mathrm{B}$ 型肝炎 & $\mathrm{B}$ 型肝炎 \\
$\mathrm{C}$ 型肝炎 & $\mathrm{C}$ 型肝炎 \\
& 結核, 肺結核, 播種性結核, 中枢神経系結核, \\
& 眼結核, 肺外結核, 潜伏結核, など 44 項目 \\
& 肺炎, 気管支肺炎, 細菌性肺炎, 肺炎球菌性 \\
肺炎 & 肺炎, ブドウ球菌性肺炎, レンサ球菌性肺炎, \\
& など 56 項目 \\
& 敗血症 \\
& 敗血症, 肺敗血症, 細菌性敗血症, 肺炎球菌 \\
& 性敗血症, ブドウ球菌性敗血症, など 53 項目
\end{tabular}


した，安全性シグナルである ROR は，既報に従 い算出し 95\%信頼区間 (confidence interval: CI) の下限值が 1 を超えた場合にシグナル有りとし た. ${ }^{16)}$ 結核に関して， 発現時期は投与開始日から 有害事象発現日までの期間を 1 力月毎に抽出し, シグナルが検出された薬剤を個別に比較するた め，報告数の最大月を 1 として各月の割合を算出 した．発現年齢は年齢デー夕を年代毎に抽出し， シグナルが検出された薬剤を個別に比較するた め, 報告数が最大の年代を 1 として各年代の割合 を算出した.

\section{結 果}

FAERS および JADER の全報告数は重複除去に より，それぞれ 29,017,485 件，2,079,653 件となっ た。また FAERS および JADER の B 型肝炎の報 告数は 4,736 件㧍よび 2,690 件, $\mathrm{C}$ 型肝炎の報告 数は 8,731 件および 544 件, 結核の報告数は 20,070 件および 4,588 件，肺炎の報告数は 239,246 件抢よび 56,057 件, 敗血症の報告数は 159,073 件
および 25,071 件であった。

FAERS，JADER における生物学的製剂による 有害事象 ( $\mathrm{B}$ 型肝炎, C 型肝炎, 結核, 肺炎, 敗 血症）の ROR（95\%CI）を表 2 に示す. B 型肝 炎について，シグナルが検出された薬剤は FAERS では abatacept 3.66 (1.18〜11.37), etanercept $1.57(1.18 \sim 2.10)$, infliximab 1.84 ( 1.34 〜2.54）であった. JADER では adalimumab 4.30 (2.14 8.62), etanercept 2.94 (1.66 5.18), infliximab 4.89 （3.32〜 7.20）であった. C 型肝炎 について, FAERSではシグナルは検出されず, JADER では etanercept 4.84（1.81〜12.96）でシグ ナルが検出された，結核について，シグナルが検 出された薬剤は FAERS では abatacept 3.17 （1.76 5.74), adalimumab 3.53 (3.21 3.89), etanercept 3.80 (3.47 4.16), infliximab 34.28 (32.87〜 35.73), tocilizumab 16.55（5.30～51.64）のすべて の薬剂であり, infliximabでは非常に高いRORを 示した. JADER では abatacept 5.78 (2.16〜 15.51), adalimumab 19.10 (14.66 24.88), etanercept 13.43 ( 10.86 16.59), infliximab 33.41 (29.43 37.92),

表 2 生物学的製剂による有害事象の ROR (95\% CI)

\begin{tabular}{|c|c|c|c|c|c|c|c|c|c|}
\hline \multirow[b]{2}{*}{ 有害事象 } & \multirow[b]{2}{*}{ 薬剤名 } & \multicolumn{4}{|c|}{ FAERS } & \multicolumn{4}{|c|}{ JADER } \\
\hline & & ROR & $95 \% \mathrm{CI}$ & $\mathrm{n} 11$ & $\mathrm{n} 1+$ & ROR & $95 \% \mathrm{CI}$ & $\mathrm{n} 11$ & $\mathrm{n} 1+$ \\
\hline \multirow{5}{*}{ B 型肝炎 } & Abatacept & 3.66 & $1.18-11.37$ & 3 & 5020 & 2.44 & $0.34-17.41$ & 1 & 317 \\
\hline & Adalimumab & 0.42 & $0.24-0.73$ & 12 & 176235 & 4.30 & $2.14-8.62$ & 8 & 1448 \\
\hline & Etanercept & 1.57 & $1.18-2.10$ & 47 & 183873 & 2.94 & 1.66- 5.18 & 12 & 3178 \\
\hline & Infliximab & 1.84 & $1.34-2.54$ & 38 & 126844 & 4.89 & $3.32-7.20$ & 26 & 4163 \\
\hline & Tocilizumab & - & - & 0 & 265 & 0.50 & $0.12-2.00$ & 2 & 3090 \\
\hline \multirow{5}{*}{$\mathrm{C}$ 型肝炎 } & Abatacept & - & - & 0 & 5020 & - & - & 0 & 317 \\
\hline & Adalimumab & 0.39 & $0.26-0.61$ & 21 & 176235 & - & - & 0 & 1448 \\
\hline & Etanercept & 0.99 & $0.76-1.30$ & 55 & 183873 & 4.84 & $1.81-12.96$ & 4 & 3178 \\
\hline & Infliximab & 0.50 & $0.32-0.78$ & 19 & 126844 & - & - & 0 & 4163 \\
\hline & Tocilizumab & - & - & 0 & 265 & 2.48 & $0.62-9.95$ & 2 & 3090 \\
\hline \multirow{5}{*}{ 結核 } & Abatacept & 3.17 & $1.76-5.74$ & 11 & 5020 & 5.78 & $2.16-15.51$ & 4 & 317 \\
\hline & Adalimumab & 3.53 & $3.21-3.89$ & 423 & 176235 & 19.10 & $14.66-24.88$ & 58 & 1448 \\
\hline & Etanercept & 3.80 & $3.47-4.16$ & 474 & 183873 & 13.43 & $10.86-16.59$ & 90 & 3178 \\
\hline & Infliximab & 34.28 & $32.87-35.73$ & 2580 & 126844 & 33.41 & $29.43-37.92$ & 271 & 4163 \\
\hline & Tocilizumab & 16.55 & $5.30-51.64$ & 3 & 265 & 3.10 & 2.02- 4.77 & 21 & 3090 \\
\hline \multirow{5}{*}{ 肺炎 } & Abatacept & 2.30 & $1.87-2.82$ & 94 & 5020 & 6.93 & $5.13-9.35$ & 51 & 317 \\
\hline & Adalimumab & 1.10 & $1.05-1.16$ & 1597 & 176235 & 7.82 & $6.83-8.95$ & 257 & 1448 \\
\hline & Etanercept & 1.05 & $1.00-1.10$ & 1586 & 183873 & 6.47 & 5.87- 7.13 & 480 & 3178 \\
\hline & Infliximab & 2.39 & $2.29-2.48$ & 2453 & 126844 & 8.57 & $7.93-9.27$ & 791 & 4163 \\
\hline & Tocilizumab & 3.26 & $1.54-6.91$ & 7 & 265 & 4.77 & $4.27-5.33$ & 359 & 3090 \\
\hline \multirow{5}{*}{ 敗血症 } & Abatacept & 2.16 & $1.67-2.79$ & 59 & 5020 & 2.12 & $1.05-4.28$ & 8 & 317 \\
\hline & Adalimumab & 0.75 & $0.70-0.81$ & 730 & 176235 & 2.27 & $1.65-3.12$ & 39 & 1448 \\
\hline & Etanercept & 0.77 & $0.71-0.82$ & 775 & 183873 & 2.31 & $1.87-2.86$ & 87 & 3178 \\
\hline & Infliximab & 1.88 & $1.78-1.98$ & 1294 & 126844 & 2.40 & $2.00-2.88$ & 118 & 4163 \\
\hline & Tocilizumab & 4.20 & $1.87-9.44$ & 6 & 265 & 2.95 & $2.43-3.58$ & 107 & 3090 \\
\hline
\end{tabular}


tocilizumab $3.10 （ 2.02 ４ .77 ）$ のすべての薬剤で あり, adalimumab, etanercept, infliximabでは特に 高值を示した. 肺炎について，シグナルが検出さ れた薬剤は FAERS では abatacept 2.30 (1.87〜2.82), adalimumab 1.10 ( $1.05 \sim 1.16)$, etanercept 1.05 ( 1.00 $\sim 1.10$ ), infliximab $2.39(2.29 \sim 2.48)$, tocilizumab 3.26 （1.54～6.91）のすべての薬剤であった. JADER で は abatacept 6.93 (5.13〜9.35), adalimumab 7.82 ( 6.83 〜 8.95), etanercept $6.47(5.87 \sim 7.13)$, infliximab 8.57 ( $7.93 \sim 9.27)$, tocilizumab $4.77(4.27 \sim 5.33)$ のす ベての薬剤であった，敗血症について，シグナル が検出された薬剤は FAERSでは abatacept 2.16 ( $1.67 \sim 2.79)$, infliximab $1.88(1.78 \sim 1.98)$, tocilizumab 4.20 （1.87～9.44）であった. JADER で は abatacept 2.12(1.05〜 4.28), adalimumab 2.27 ( 1.65 3.12), etanercept $2.31(1.87 \sim 2.86)$, infliximab 2.40 (2.00〜2.88), tocilizumab $2.95(2.43 \sim 3.58)$ のす べての薬剤であった。

結核の発現時期について, FAERSおよび JADER における結核の報告数の最大を 1 として 各月の割合を算出したグラフを図 1 および図 2 に 示す. FAERS, JADER ともに薬剂別での発現時 期の検討は報告数が少なく解析が困難であったた め，生物学的製剤としてまとめて検討し傾向を把 握した. FAERS では全薬剤による結核が投与後 1 カ月でピーク（865 件 / 3,170 件）を示し，その 後，急激な減少を示したことに対して，生物学的 製剂 5 種類による結核は投与後 4 力月でピーク

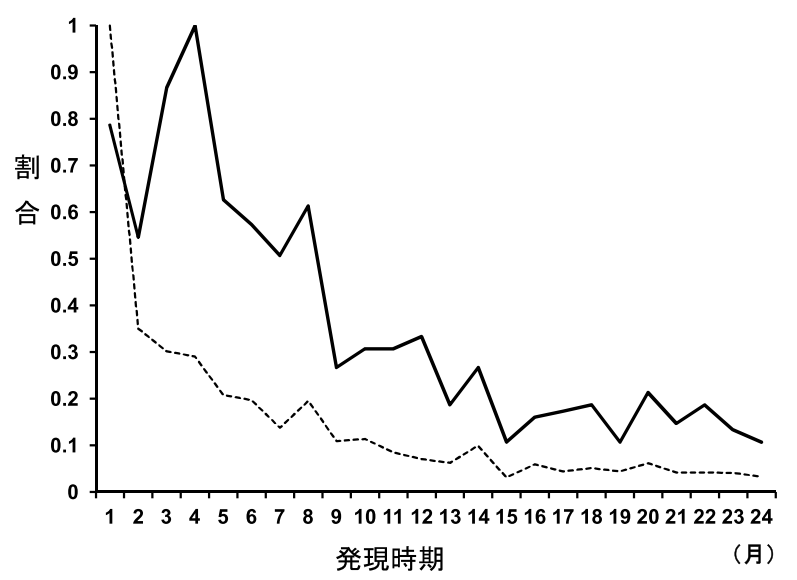

図 1 FAERS における結核の発現時期 - - - 全薬郕による結核, 一一生物学的製剤 5 種類による結核.
（75 件 / 653 件）を示し, 投与後 1〜 5 力月で高值 を示した. JADER では全薬剤による結核は投与 後 1 カ月でピーク（302 件 / 1,597 件）を示し, 生物学的製剤 5 種類による結核も投与後 1 力月で ピーク（71 件 / 284 件）を示し, いずれも投与後 1〜2 カ月で高值を示した。

結核の発現年歯について, FAERS および JADER における結核の報告数の最大を 1 として各年代の 割合を算出したグラフを図 3 および図 4 に示す. FAERS, JADER ともに薬剤別での発現年龄の検 討は報告数が少なく，解析が困難であったため, 生物学的製剤としてまとめて検討し傾向を把握し た. FAERSでは全薬剤による結核は 60 代でピー ク（453 件 / 2,316 件）を示し, 生物学的製剤 5

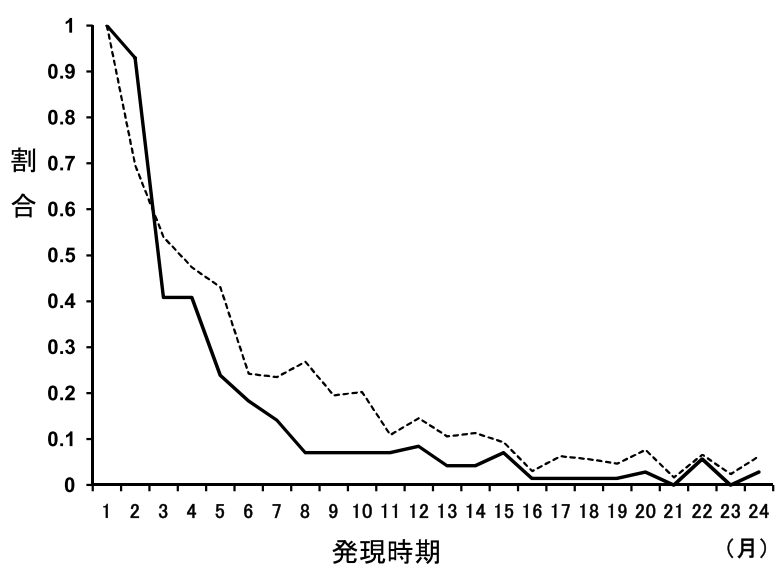

図 2 JADER における結核の発現時期 - - - 全薬剤による結核, 一生物学的製剂 5 種類による結核.

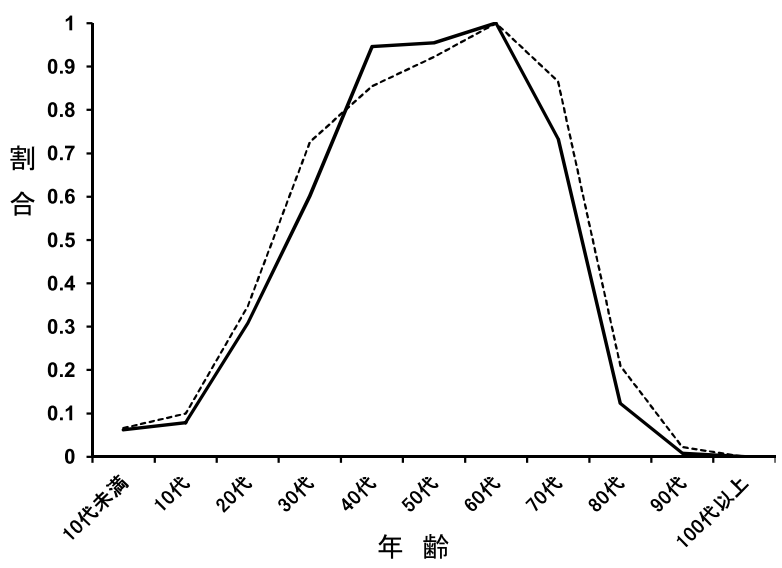

図３ＦAERS における結核の発現年齢 - - - 全薬剂による結核, 一一生物学的製剂 5 種類による結核。 


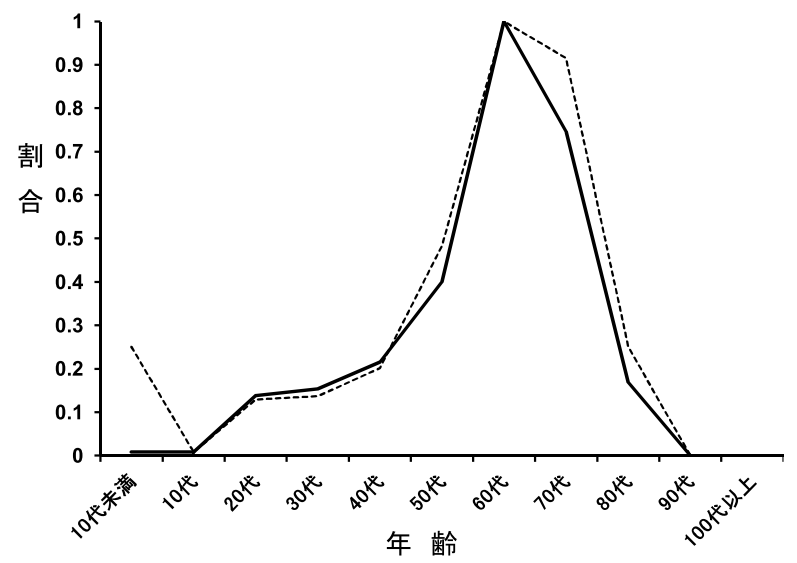

図4 JADER における結核の発現年齢 - - - 全薬剤による結核, 一生物学的製剂 5 種類による結核.

種類による結核も 60 代でピーク（243 件 / 1,170 件）を示した，全薬剤による結核，生物学的製剤 5 種類による結核はともに 30～70 代と幅広い範 囲で高值を示した。JADERでは全薬剤による結 核は 60 代でピーク（248 件 / 837 件）を示し，生 物学的製剤 5 種類による結核も 60 代でピーク （130 件／ 369 件）を示した. 全薬剤による結核， 生物学的製剤 5 種類による結核はともに 60 ～ 70 代で高値を示した.

\section{考察}

FAERS およびJADER の報告数の比率に関して, 全報告において FAERS（29,017,485 件）は JADER $(2,079,653$ 件) の 14 倍に対し, B 型肝炎 1.8 倍, C 型肝炎 16 倍, 結核は 4.4 倍, 肺炎 4.3 倍, 敗血 症 6.3 倍である. 生物学的製剤 5 種類による対象 有害事象の報告数（n11）において, FAERS と JADER の比率は，B 型肝炎 2.0 倍（FAERS 100 件 / JADER 49 件), C 型肝炎 16 倍（95/6）, 結核は 7.9 倍 $(3,491 / 444)$, 肺炎 3.0 倍 $(5,737$ / 1,938), 敗 血症 8.0 倍（2,864/359）である. FAERS および JADER の報告数の比率は， C 型肝炎は全報告と同 等であり, C 型肝炎以外の対象有害事象は FAERS に比べ JADER のほうに偏りがある。この偏りは, 両データベースの背景の違いや自発報告の解析の 限界であるバイアスによる影響などが考えられた。

FAERS において B 型肝炎のシグナルが検出さ
れた薬剤は abatacept, etanercept, infliximab であり, JADER において B 型肝炎のシグナルが検出され た薬片は adalimumab, etanercept, infliximab であっ た. FAERS, JADER ともにシグナルが検出され た etanercept, infliximab では特に B 型肝炎の発症 に注意が必要であると考える. B 型肝炎の再燃に よって発症する de novo B 型肝炎は通常の B 型肝 炎に比べて劇症化する頻度が高率で, 死亡率も高 いことが特徵的である. ${ }^{17}$ 特に抗 CD20 モノクロー ナル抗体である rituximabの使用における発症が 問題となっていたが，TNF 阻害薬の使用でも発 症の報告がある. ${ }^{18)}$ 日本リウマチ学会のガイドラ インでは今回解析した生物学的製剂 5 種類すべて において B 型肝炎への注意喚起がなされており， 投与前のスクリーニングと投与後のモニタリング が推奨されている. tocilizumab を除く 4 種類の生 物学的製剂においては投与により B 型肝炎が発 症したという報告があり, ${ }^{2-9)}$ tocilizumab の今後の 報告数の蓄積に留意しながら, 生物学的製剂は $\mathrm{B}$ 型肝炎に注意した使用が望まれる。

一般的に生物学的製郕による肝炎の発症では B 型肝炎を指すことが多いが，C 型肝炎の発症も患 者の予後に多大なる影響を及ぼすと考え, 本研究 では C 型肝炎に関しても同様に解析を行った。 C 型肝炎において FAERS ではシグナルは検出され ず，JADER では etanercept でシグナルが検出され た. C型肝炎の発症に扔いて, TNF 阻害薬, tocilizumab のガイドラインでは一定の見解は得ら れていないが，慎重な対応をすべきであると記載 されている。 なお abataceptのガイドラインでは $\mathrm{C}$ 型肝炎に関する記載はない。生物学的製剤によ る $\mathrm{C}$ 型肝炎発症に関する報告は散見され， C 型 肝炎ウイルス陽性リウマチ患者への etanercept の 投与で $\mathrm{C}$ 型肝炎が再活性化した例が報告されて いる. ${ }^{19)}$ 一方, C 型肝炎ウイルス陽性リウマチ患者 への TNF 阻害薬である adalimumab, etanercept, infliximab の投与は安全とみなした報告もある. ${ }^{20-22)}$ このように生物学的製剤と C 型肝炎の関連は未だ 不明瞭な点が多い. 生物学的製剤は prednisolone, methotrexate 等の免疫抑制作用のある薬剤と併用 されることが多いことが一因として挙げられると 考える. 現時点で, 生物学的製剤のみが $\mathrm{C}$ 型肝 
炎に影響しているとは考え難い.JADER でシグ ナルが検出された etanerceptによる C 型肝炎は, 今後の報告数の蓄積に留意すべきであると考える.

結核ではFAERS，JADER ともにすべての生物 学的製剂でシグナルが検出された，解析した生物 学的製剤を用いることができる国や地域は医療水 準が高く, 結核に対する予防法が確立されており， これらの薬剤による有害事象として報告された結 核は自然発生した結核ではなく，生物学的製剤に よる影響が大きいと予想される。. ${ }^{23)}$ 今回の結果か らも，生物学的製剂による結核を予防するために は，日本リウマチ学会のガイドラインに則り, 投 与前のスクリーニングと投与後のモニタリングが 遵守されるべきである. abatacept は infliximab と 比べて, 有害事象の発現が少なく, 相対的に安全 性が高いという報告があるが, ${ }^{24,25)}$ 今回シグナル が検出され，使用ガイドラインで要注意事項とし て取り上げられていること等を考慮すると， infliximab と同様に結核に対して十分な注意が必 要であると考える.TNF 阻害薬である adalimumab, etanercept, infliximabに関しては今回シグナルが 検出され，結核発症に関する報告が多数ある. ${ }^{10-12}$ TNF- $\alpha$ は結核病巣の肉芽腫形成に重要な役割を 果たしており，肉芽腫は結核菌を封じ込める作用 があるため, TNF 阻害薬の使用は結核の再燃に 関連すると考えられており, ${ }^{26} \mathrm{TNF}$ 阻害薬投与時 は結核に特に注意が必要である。FAERSにおい て infliximabによる結核の ROR はほかの薬郕と 比較して高值である。これは同類薬の中で最も早 く発売されたことにより, 結核の有害事象が注目 され，報告数が多くなったと考えられる．また infliximabにより生物学的製剤による結核の意識 が根付き，スクリーニング等の必要性が周知され たため, その後, 発売された薬片では, 結核の発 症が減少したと考えられている. 27)さらに infliximab は methotrexate との併用が義務付けら れているため, methotrexateの影響で免疫抑制作 用が強く発現したことも考えられる. tocilizumab に関しては, 我々の結果も含めて, 現時点では報 告数が少ないため, さらなるデー夕の蓄積が必要 である。

肺炎においても FAERS，JADER ともにすべて
の薬剤でシグナルが検出され，それぞれの添付文 書に肺炎に関する記載があることから, 生物学的 製剤使用時は肺炎に注意した使用が望まれる。特 に infliximabでは, 今回の解析でFAERSにおけ る RORが 2.39 (2.29〜2.48), JADERにおける ROR が 8.57 （7.93〜9.27）を示し, 高いシグナル が検出された. 5000 例の市販後調查の結果でも

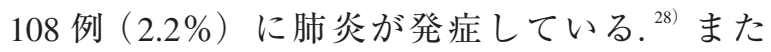
infliximab の投与で肺炎が発症した報告もある. ${ }^{13}$ 高齢者における肺炎の罹患は QOL の観点からも 危惧されている。肺炎はわが国の死亡原因の 3 位 に位置していること等も考慮すると, いずれの薬 凨の使用時も肺炎に注意すべきであると考える. 我々は肺炎に着目して解析を行ったが，感染性・ 非感染性を区分した解析まで至らなかった。 FAERS およびJADER から得られる情報のみでは 判断が困難な場合があり今後の課題である. 生物 学的製剂の有害事象による感染症において, 結核 が重点的に研究されており, 肺炎に主眼を置いて いる文献は少なかった，今回の解析を契機にさら なる研究がなされることが望まれる.

敗血症においても重篤な感染症という観点から 解析を行った. FAERSでは abatacept, infliximab, tocilizumab でシグナルが検出され，JADER では 5 種類すべてでシグナルが検出された. 添付文書に おいて，すべての薬剤で敗血症に関する記載があ り, 今回の結果からも, 感染症が重篤化した状態 である敗血症に対し留意した使用が望まれる。

結核発症の発見の遅れは，その間に患者が重症 化し排菌量が増加する可能性が高まり，周囲への 感染リスクが増大するため, 結核発症には注意深 いサーベイランスが必要とされている. ${ }^{1)}$ 結核の 発現時期に関して, 生物学的製剤による結核は FAERS では投与後 1〜 5 カ月で高值を示し, JADER では投与後 1〜2 カ月で高值を示した。こ れは結核の初発症状に対する地域間の対応の違い が関係していると考えられる. 日本は欧米に比べ, 結核罹患者が多く, 国内で話題となっている背景 があり，医療従事者が結核の初期症状に敏感であ ることが考えられる. しかし, 結核の発現時期に 差が生じた明確な理由は見出せなかった。JADER で生物学的製剤投与初期の報告が目立ったことか 
ら，欧米でも生物学的製剤投与初期に結核発現の 診断を下すことが可能であると予想され，以前に 比して早期の対応が可能になると考えられる. infliximab では投与後 3 力月頃で結核の発現が多 いと報告があり, ${ }^{23,29)}$ adalimumab, etanercept, infliximab の長期投与において結核が発現した報 告もある. ${ }^{10)}$ よって生物学的製剤投与時は少なく とも 1〜 5 カ月は結核の発現に注意すべきである.

結核の発現年齢に関して, 全薬剂による結核, および生物学的製剤 5 種類による結核は FAERS では 30〜 70 代と幅広い年代で高值を示したこと に対し，JADERでは 60〜 70 代で高值を示した。 これは米国での結核の発現が若, 中年層に多く,

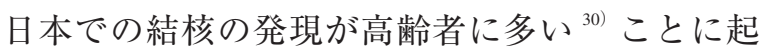
因していると考えられる。つまり FAERS，JADER に扔ける結核の発現年齢の違いは生物学的製剤に よる影響よりも母集団の結核の罹患年齢が関与し ていると考えられる．よって薬剤別に結核への対 応を変えるよりも，母集団の結核の罹患年齢を考 慮して対応することが重要であると考えられる. 現在，日本では 20〜30 代の若年者の結核感染が 増加傾向にある. ${ }^{30)}$ 結核キャリアが若年者で増加 すると, 生物学的製剂投与時の注意喚起が不十分 であれば，今後若年層で結核発現が増加すること も考えられる。

FAERS や JADER 等の有害事象自発報告データ ベースの解析は，薬剤と有害事象を個別に認識す ることを可能にし，医療安全の面で多大なる貢献 ができる，有害事象自発報告データベースは未知 の重篤な有害事象を検出するための最も優れた手 段である. ${ }^{14)}$ しかし，自発報告であるがゆえに解 析には限界があり，過少報告，詳細な臨床情報の 不足, 安全性情報等の影響による過剩報告, 発売 時期における報告数の増加, 重複デー夕の存在等 が知られており， ${ }^{31-34)}$ 有害事象自発報告データベー スから得られた情報の解釈には注意が必要である。 世界保健機関 (World Health Organization: WHO)は, シグナルとは「それまで知られなかったか，もし くは不完全にしか立証されていなかった薬剤と有 害事象との因果関係の可能性に関する, さらに検

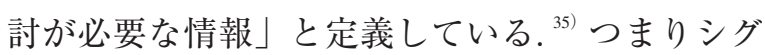

ナル検出を行うだけではなく, 発現時期, 発現年 齢を解析し，ほかの文献等を参考にすることで, 有害事象に対するリスクを最小限にして，適切な 医療を提供することが可能となる.特に発現時期, 発現年齢の解析は有害事象の早期発見, 早期対応 に直結し，重篤化前の対処を可能にする。また不 可逆的な有害事象に対しても早期の適切な対応に より, 不測の事態を避けることができるため, 発 現時期および発現年齢の解析は臨床上, 非常に有 効な手段である。対象有害事象である B 型肝炎, $\mathrm{C}$ 型肝炎, 結核, 肺炎, 敗血症はいずれも重篤な 有害事象であり，これらが治療中に発現すると生 命の危機にかかわることが予想される．また生物 学的製剤を投与される患者は臨床的状態が不良で あることが多い。よって有害事象の発現は原疾患 の治療期間の延長，薬剂の減量等の対応を必要と し，患者の予後に多大な影響を及ぼすと考えられ る.

European Medicines Agency (EMA) の guideline on good pharmacovigilance practices (GVP) Module IX - Signal management (http://www.ema.europa.eu/ docs/en_GB/document_library/Scientific_guideline/ 2012/06/WC500129138.pdf, 2014 年 5 月 15 日）で は, 統計的解析は有害事象を見出す最初の段階 にすぎないことを示している。 また，国際医学団 体協議会 (Council for International Organizations of Medical Science: CIOMS）は, 有害事象自発報告デー タベースの統計的解析は慎重かつ適切な臨床的判 断に代わるものではないと示し, その限界に留意し たうえで，自発報告システムに基づく有害事象の 評価の必要性や重要性について明示している.

本研究では, 有害事象自発報告データベースで ある FAERS および JADER から, 既知の事象で ある生物学的製剂と B 型肝炎, 結核, 肺炎, 敗 血症の関連が陽性対照として示された。一定の見 解が得られていない未知の事象である生物学的製 剤と C 型肝炎の関連については, JADER でシグ ナルが検出された etanerceptによる C 型肝炎に注 目が必要と思われた。また，結核の発現時期，発 現年齢等の未だ不明暸な事象の関連を示すことが できた。特に発現時期に関してはFAERS, JADER を解析して, 両データベース間の違いを 
考察することで, 一方のデータベースだけでは検 証が不十分であった事象について，薬片と有害事 象の関連をより明確化できた. FAERS と JADER の比較に関しては，日本発の生物学的製剂である tocilizumab はFAERS の少ない報告数に比して, JADER では多数の報告があった. tocilizumabで はJADER の解析結果が海外にむけた参考となる 可能性がある．FAERS，JADERを解析し，互い にデータを補完し合うことで海外と日本の有害事 象の発現傾向の違いを把握でき, 臨床現場での活 用が期待できる。よって FAERS と JADERのよ うなデータベースの比較，検討は非常に有用と考 えられた。

\section{引用文献}

1) Ohmori M, Ozasa K, Mori T, Wada M, Yoshiyama T, Aoki M, Uchimura K, Ishikawa N, Trends of delays in tuberculosis case finding in Japan and associated factors, Int J Tuberc Lung Dis, 2005, 9, 999-1005.

2) Germanidis G, Hytiroglou P, Zakalka M, Settas L, Reactivation of occult hepatitis B virus infection, following treatment of refractory rheumatoid arthritis with abatacept, J Hepatol, 2012, 56, 1420-1429.

3) Robinson H, Walker-Bone K, Anti-TNF- $\alpha$ therapy for rheumatoid arthritis among patients with chronic hepatitis B infection, Rheumatology, 2009, 48, 448450.

4) Madonia S, Orlando A, Scimeca D, Olivo M, Rossi F, Cottone M, Occult hepatitis B and infliximab-induced HBV reactivation, Inflamm Bowel Dis, 2007, 13, 508-509.

5) Esteve M, Saro C, González-Huix F, Suarez F, Forné M, Viver JM, Chronic hepatitis B reactivation following infliximab therapy in Crohn's disease patients: need for primary prophylaxis, Gut, 2004, 53, 1363-1365.

6) Wendling D, Auge B, Bettinger D, Lohse A, Le Huede G, Bresson-Hadni S, Toussirot E, Miguet JP, Herbein G, Di Martino V, Reactivation of a latent precore mutant hepatitis B virus related chronic hepatitis during infliximab treatment for severe spondyloarthropathy, Ann Rheum Dis, 2005, 64, 788-789.

7) Montiel PM, Solis JA, Chirinos JA, a Casis B, Sánchez F, Rodríguez S, Hepatitis B virus reactiva- tion during therapy with etanercept in an HBsAgnegative and anti-HBs-positive patient, Liver Int, 2008, 28, 718-720.

8) Ostuni P, Botsios C, Punzi L, Sfriso P, Todesco S, Hepatitis B reactivation in a chronic hepatitis B surface antigen carrier with rheumatoid arthritis treated with infliximab and low dose methotrexate, Ann Rheum Dis, 2003, 62, 686-687.

9) Matsumoto T, Marusawa H, Dogaki M, Suginoshita Y, Inokuma T, Adalimumab-induced lethal hepatitis $B$ virus reactivation in an $\mathrm{HBs} A g$-negative patient with clinically resolved hepatitis B virus infection, Liver Int, 2010, 30, 1241-1242.

10) Shaikha SA, Mansour K, Riad H, Reactivation of Tuberculosis in Three Cases of Psoriasis after Initiation of Anti-TNF Therapy, Dermatology, 2012, 4, 41-46.

11) Mankia S, Peters JE, Kang S, Moore S, Ehrenstein MR, Tuberculosis and anti-TNF treatment: experience of a central London hospital, Clin Rheumatol, 2011, 30, 399-401.

12) Malipeddi AS, Rajendran R, Kallarackal G, Disseminated tuberculosis after anti-TNF $\alpha$ treatment, Lancet, 2007, 369, 162.

13) Kodama K, Nagai T, Ogawa E, Tanaka J, Hoshi K, Tanaka S, Hirohata S, A case of recurrence of Pneumocystis jirovecii pneumonia with rheumatoid arthritis after cessation of biological agents, 北里医 学, 2011, 41, 127-131.

14) Fujita T, Signal Detection of Adverse Drug Reactions, Jpn J Pharmacoepidemiol, 2009, 14, 27-36.

15) Rothman KJ, Lanes S, Sacks ST, The reporting odds ratio and its advantages over the proportional reporting ratio, Pharmacoepidem Dr S, 2004, 13, 519-523.

16) van Puijenbroek EP, Bate A, Leufkens HG, Lindquist M, Orre R, Egberts AC, A comparison of measures of disproportionality for signal detection in spontaneous reporting systems for adverse drug reactions, Pharmacoepidem Dr S, 2002, 11, 3-10.

17) Tsubouchi H, Kumada H, Kiyosawa K, Mochida S, Sakaida I, Tanaka E, Ichida T, Mizokami M, Suzuki K, Yoshiba S, Moriwaki H, Hibi T, Hayashi N, Kokudo N, Fujisawa T, Ishibashi H, Sugawara Y, Yatsuhashi H, Ido A, Takikawa Y, Inoue K, Oketani M, Uto H, Nakayama N, Naiki T, Tada S, Kiso S, Yano K, Endo R, Tanaka Y, Umemura T, Kumagai K, Prevention of immunosuppressive therapy or che- 
motherapy-induced reactivation of hepatitis B virus infection -Joint report of the Intractable Liver Diseases Study Group of Japan and the Japanese Study Group of the Standard Antiviral Therapy for Viral Hepatitis-, Kanzo, 2009, 50, 38-42.

18）田中榮司, B型肝炎再活性化の病態と対策, 日本 消化器病学会雑誌, 2010, 107, 1417-1425.

19）阿部和道, 塩 季織, 大平弘正, TNF阻害薬と肝 炎ウイルスの活性化, 分子リウマチ治療, 2009, 2, 92-94.

20) Peterson JR, Hsu FC, Simkin PA, Wener MH, Effect of tumour necrosis factor alpha antagonists on serum transaminases and viraemia in patients with rheumatoid arthritis and chronic hepatitis $\mathrm{C}$ infection, Ann Rheum Dis, 2003, 62, 1078-1082.

21) Roux CH, Brocq O, Breuil V, Albert C, EullerZiegler L, Safety of anti-TNF- $\alpha$ therapy in rheumatoid arthritis and spondylarthropathies with concurrent B or C chronic hepatitis, Rheumatology, 2006, 45, 1294-1297.

22) Bellisai F, Giannitti C, Donvito A, Galeazzi M, Combination therapy with cyclosporine A and antiTNF-alpha agents in the treatment of rheumatoid arthritis and concomitant hepatitis $\mathrm{C}$ virus infection, Clin Rheumatol, 2007, 26, 1127-1129.

23) Keane J, Gershon S, Wise RP, Mirabile-Levens E, Kasznica J, Schwieterman WD, Siegel JN, Braun MM, Tuberculosis Associated with Infliximab, a Tumor Necrosis Factor $\alpha-$ Neutralizing Agent, $N$ Engl J Med, 2001, 345, 1098-1104.

24) Rodrigues CE, Vieira FJ, Callado MR, Gomes KW, de Andrade JE, Vieira WP, Use of the abatacept in a patient with psoriatic arthritis, Bras J Rheumatol, 2010, 50, 343-345.

25) Schiff M, Keiserman M, Codding C, Songcharoen S, Berman A, Nayiager S, Saldate C, Li T, Aranda R, Becker JC, Lin C, Cornet PL, Dougados M, Efficacy and safety of abatacept or infliximab vs placebo in ATTEST: a phase III, multi-centre, randomised, double-blind, placebo-controlled study in patients with rheumatoid arthritis and an inadequate response to methotrexate, Ann Rheum Dis, 2008, 67, 10961103.

26) Flynn JL, Chan J, Immunology of tuberculosis, Anпи Rev Immunol, 2001, 19, 93-129.

27）川合眞一, エタネルセプトの適応と使い方, 医学 のあゆみ, 2007, 221, 388-392.

28) Sugita $T$, Targeting Therapy for Inflammatory Diseases by Anti-TNFa Biologics, YAKUGAKU ZASSHI, 2009, 129, 19-24.

29) Gómez-Reino JJ, Carmona L, Valverde VR, Mola EM, Montero MD; BIOBADASER Group, Treatment of Rheumatoid Arthritis With Tumor Necrosis Factor Inhibitors May Predispose to Significant Increase in Tuberculosis Risk, Arthritis Rheum, 2003, 48, 2122-2127.

30）石川信克，わが国の結核対策の現状と課題（3） 「世界, 日本の結核の疫学と課題」, 日本公衆衛生 雑誌, 2008, 55, 791-794.

31) Wise L, Parkinson J, Raine J, Breckenridge A, New approaches to drug safety: a pharmacovigilance tool kit, Nat Rev Drug Discov, 2009, 8, 779-782.

32) Sakaeda T, Tamon A, Kadoyama K, Okuno Y, Data Mining of the Public Version of the FDA Adverse Event Reporting System, Int J Med Sci, 2013, 10, 796-803.

33) Poluzzi E, Raschi E, Piccinni C, Ponti FD, "Data Mining Applications in Engineering and Medicine”, ed by Karahoca A, InTech, Croatia, 2012, pp265302.

34) Motola D, Vargiu A, Leone R, Conforti A, Moretti U, Vaccheri A, Velo G, Montanaro N, Influence of regulatory measures on the rate of spontaneous adverse drug reaction reporting in Italy, Drug Saf, 2008, 31, 609-616.

35) Edwards IR, Lindquist M, Wiholm B-E, Napke E, Quality criteria for early signals of possible adverse drug reactions, Lancet, 1990, 336, 156-158.

36）〈すりの適性使用協議会監訳, ファーマコビジ ランスにおけるシグナル検出の実践, レーダー 出版センター, 東京, 2011, pp1-10. 